Brit. F. vener. Dis. (1969), 45, 44.

\title{
ISOLATION OF TRIC AGENTS FROM THE HUMAN GENITAL TRACT*
}

\author{
BY \\ DENYS K. FORD AND LIANNE McCANDLISH \\ Department of Medicine, Vancouver General Hospital and University of British Columbia, Vancouver, B.C., Canada
}

Dunlop, Harpcr, Al-Hussaini, Garland, Treharne, Wright, and Jones (1966) reviewed the relation of TRIC (trachoma-inclusion conjunctivitis) agents to non-specific genital infection and described their experience in the isolation of these agents from scveral categorics of patients. Stimulated by this report and that of Schachter, Barnes, Jones, Engleman, and Mcyer (1966) on the isolation of Bedsonia agents from patients with Reiter's syndrome, we employed the egg yolk-sac technique of T'ang, Chang, Huang, and Wang (1957) to find the incidence of isolation of TRIC agents from pationts in Vancouver, British Columbia.

\section{Methods}

Patients attending the Vancouver V.D. Control Clinic for non-gonococcal urethritis were selected for study if the urethral exudate showed no gonococci by stained smear and/or culture, and if definite clinical evidence of urethritis could be found. A Dunlop-Jones curette was used to obtain urethral scrapings immediately after the patient had urinated. The scrapings were transferred to $4 \mathrm{ml}$. sterile broth or Snyder's solution (sucrose-potassium-glutamate).

As a control group, similar urethral scrapings were obtained from male patients at diagnostic cystoscopy for conditions other than lower uro-genital tract infections. These patients had not received broad-spectrum antibiotics and were of approximately the same age as the patients with non-gonococcal urethritis.

Three groups, of women were studied: new inmates at a local gaol, out-patients attending a hospital gynaecology clinic, and private patients of four gynaecologists. Specimens were obtained from the cervix with wooden spatulae designed for taking Papanicolaou smears.

During the 2-year study, patients with Reiter's syndrome were studied whenever possible, and urethral scrapings, conjunctival scrapings, synovial fluid, and synovial biopsies were obtained and inoculated into eggs.

Antibiotics were added to the specimens in broth or

$\star^{\star}$ Received for publication September 20, 1968.
Snyder's solution as follows: streptomycin to $5.0 \mathrm{mg} . / \mathrm{ml}$. and neomycin to $0.5 \mathrm{mg} . / \mathrm{ml}$. to all specimens and, in addition, vancomycin to $1 \mathrm{mg} . / \mathrm{ml}$. and nystatin to 100 units $/ \mathrm{ml}$. to the cervical scrapings from female patients.

The specimens were kept at room temperature for at least 1 hour before $0.5 \mathrm{ml}$. was inoculated into each of four to six yolk sacs of embryonated eggs incubated at $38^{\circ} \mathrm{C}$. for 6 to 8 days. After inoculation the eggs were incubated at 35 to $35.5^{\circ} \mathrm{C}$. for 13 days and candled daily. Eggs dying in the first 4 days were discarded, but all other eggs, either at death or after 13 days' incubation following inoculation, were tested for bacterial sterility and examined for elementary bodies. Yolk sacs were removed aseptically and smears made of the yolk stalk. These smears were heat-fixed and stained by the method of Giménez (1964). The yolk sacs were stored overnight in the refrigerator until bacterial sterility was determined. The next day the sacs were ground up, using a mortar, pestle, carborundum powder, and Snyder's solution with neomycin and streptomycin. The resultant suspension was centrifuged at $1000 \mathrm{G}$ for 1 hour at $0^{\circ} \mathrm{C}$. The middle layer of the centrifuged material was used for passage into new 6 to 8-day-old eggs. At least one blind passage was performed on each case. Brothinoculated groups of control eggs were carried throughout the study to monitor for laboratory cross-contamination.

\section{Results}

Table 1 (opposite) shows that 148 patients with uncomplicated non-gonococcal urethritis were studied and that in fifteen cases bacterial contamination of eggs occurred. Of the remaining 133 cases fifteen yiclded serially passageable elementary bodies characteristic of TRIC agents, an incidence of 11.3 per cent. Yolk-sac material from twelve of these fifteen cases was sent to Dr. J. Schachter in San Francisco, who demonstrated complementfixing Bedsonia antigen in all except one. In this latter case it was subsequently found that the yolk sacs had been contaminated with $M$. gallisepticum and elementary bodies were no longer demonstrable. The TRIC agent elementary bodies were 
TABLE I

TRIC ISOLATIONS FROM MALE AND FEMALE SUBJECTS

\begin{tabular}{|c|c|c|c|c|c|c|}
\hline Series & $\begin{array}{c}\text { Total } \\
\text { Studied }\end{array}$ & $\begin{array}{c}\text { Bacterial } \\
\text { Contamination }\end{array}$ & $\begin{array}{l}\text { Unexplained } \\
\text { Egg Deaths }\end{array}$ & $\begin{array}{l}\text { Satisfactorily } \\
\text { Studied }\end{array}$ & $\begin{array}{l}\text { TRIC } \\
\text { Isolates }\end{array}$ & $\begin{array}{l}\text { Percentage of } \\
\text { satisfactorily } \\
\text { studied Cases } \\
\text { TRIC +- }\end{array}$ \\
\hline $\begin{array}{l}\text { Males } \\
\text { Non-gonococcal Urethritis Cases } \\
\text { Controls }\end{array}$ & $\begin{array}{r}148 \\
33\end{array}$ & $\begin{array}{l}15 \\
10\end{array}$ & 二 & $\begin{array}{r}133 \\
23\end{array}$ & $\begin{array}{r}15 \\
0\end{array}$ & $\underset{0}{11 \cdot 3}$ \\
\hline Females & $111^{\star}$ & 37 & 30 & 44 & 0 & 0 \\
\hline
\end{tabular}

$\star 62$ gaol inmates, 33 private patients, 16 hospital out-patients.

seen in the yolk-sac smears from the original eggs in four cases and in the smears of the first-passage eggs in eleven cases.

Four of the serially propagated agents were injected intracerebrally into 2 to 3 -week-old white Swiss mice, $0.04 \mathrm{ml}$. of an inoculum containing $10^{6}$ egg-infective units being employed, but they were not pathogenic by this route.

Coincidental isolation of $\mathrm{T}$-strain mycoplasmata was attempted from the first 100 urethral scrapings. Table II shows that seven isolations of TRIC agents were made from 73 patients in whom mycoplasmata were found, whereas five TRIC isolates were obtained from 27 patients in whom no $\mathrm{T}$-strains were demonstrated.

TABLE II

CORRELATION BETWEEN T-STRAIN AND TRIC ISOLATIONS IN 100 CASES OF NON-GONOCOCCAL URETHRITIS

\begin{tabular}{c|c|c}
\hline \multicolumn{2}{|c|}{ Results of Culture } & No. of Cases \\
\cline { 1 - 2 } T-strain & TRIC & - \\
\hline$\vdots$ & + & 7 \\
- & - & 66 \\
5 \\
- & - & 22 \\
\hline
\end{tabular}

Elementary bodies were not found in 23 adequately studied scrapings from the group of men undergoing diagnostic cystoscopy.

In the study of female subjects, a considerable proportion of the eggs became contaminated with bacteria and monilia, in spite of the additional incorporation of both vancomycin and nystatin in the inocula. In addition, unexplained embryo deaths occurred when eggs were inoculated with cervical scrapings. Table I also shows that although 111 women were investigated a satisfactory study was completed in only 44 cases. No TRIC agents were isolated from any of these women.

During the 2-year period of this investigation twelve patients with Reiter's syndrome were seen and considered reasonable subjects for inclusion into the investigation. Nine synovial and four conjunctival specimens were inoculated into eggs but yielded no Bedsonia agents. Two of the patients had acute untreated disease and satisfactory samples of synovial fluid, conjunctival scrapings, and urethral scrapings were all negative. In the other cases, however, the sub-acuteness of the disease, the possibility of prior penicillin or sulphonamide therapy, and technical factors in the laboratory may have excluded them from being fair subjects.

\section{Discussion}

TRIC agents must be considered potential pathogens in at least 10 to 15 per cent. of cases of non-gonococcal urethritis. Our data do not prove that they were, in fact, the cause of the disease and in seven of twelve cases the agents were associated with $T$-strain mycoplasmata, also potential pathogens. Non-gonococcal urethritis is successfully treated by either tetracycline or erythromycin and both types of microbiological agent are sensitive to these antibiotics. Unfortunately we have been unable, for a variety of technical reasons, to develop serological methods to study the presence of serum antibody against these particular agents.

The failure to find TRIC agents in 44 women was somewhat surprising, particularly as 22 were gaol inmates who can probably be assumed to be promiscuous. Consideration was given to the possibility that vancomycin was inhibitory to TRIC agents in spite of the report of their resistance (Jenkin and Hung, 1967). In our laboratory, however, no inhibition of a serially propagated recent TRIC isolate by vancomycin could be demonstrated up to a concentration of $8 \mathrm{mg}$./egg and in two cases new isolates were obtained from patients with non-gonococcal urethritis when 1 $\mathrm{mg} . / \mathrm{ml}$. was included in the inoculum. During the time of this study it was not possible to use ristocetin as it was not obtainable in Canada after 1965. 
The failure to find Bedsonia agents in any specimen from a patient with Reiter's syndrome may, or may not, be significant. Serological data obtained in this laboratory have shown no significant difference, in the incidence or titre of complementfixing antibody against a psittacosis antigen, between patients with Reiter's syndrome and unselected patients attending a V.D. clinic (Ford, 1968). The two data together might suggest that Bedsonia agents are not closely related to the etiology of Reiter's syndrome.

\section{Summary}

TRIC agents were isolated from urethral scrapings of fifteen of 133 patients with nongonococcal urethritis, an incidence of 11.3 per cent. No TRIC isolates were obtained from 23 "control" men or from the cervical scrapings of 44 women.

The authors wish to thank Mrs. Joyce Macdonald, Mrs. Brenda Rhodes, and Mrs. Ruth Sigal for technical assistance in the earlier phases of the study. They are also grateful to Dr. J. Schachter, G. W. Hooper Foundation, San Francisco, for help in developing the techniques and for demonstrating Bedsonia antigen in yolk-sac material of the positive cases. They also acknowledge the co-operation of the staff of the Vancouver V.D. Control Clinic. The work was supported by Federal Health Grant No. 609-7-171.

\section{REFERENCES}

Dunlop, E. M. C., Harper, I. A., Al-Hussaini, M. K., Garland, J. A., Treharne, J. D., WRight, D. J. M. and JONES, B. R. (1966). Brit. F. vener. Dis., 42, 77.

FoRD, D. K. (1968). Canad. med. Ass. F., 99, 900.

GiMENEZ, D. F. (1964). Stain technol., 39, 135.

Jenkin, H. M., and HuNG, S. C. (1967). Appl. Microbiol., $15,10$.

SChachter, J., Barnes, M. G., Jones, J. P., Engleman, E. P., and MeYrR, K. F. (1966). Proc. Soc. exp. Biol. (N.Y.), 122, 283.

T'Ang, F. F., Chang, H. L., Huang, Y. T., and Wang, K. C. (1957). Chin. med. F., 75, 429.

\section{L'isolement des agents "TRIC" des voies génitales humaines \\ RÉSUMÉ}

Les agents "TRIC" ont été isolés des grattages urétraux de quinze des 113 malades atteints d'urétrite non-blennorragique, une incidence de 11,3 pour cent. Aucun isolate "TRIC" n'avait été obtenu des 23 hommes "témoins" ou des grattages cervicaux de 44 femmes. 